\title{
Effect of acute cigarette smoking on gastric secretion
}

\author{
J C Roxburgh, P F Whitfield, M Hobsley
}

\begin{abstract}
The effects of smoking one cigarette on a plateau of submaximal gastric secretion induced by histamine acid phosphate $(16 \mathrm{nmol}$ $\left.\mathrm{kg}^{-1} \mathrm{~h}^{-1}\left(0.005 \mathrm{mg} \mathrm{kg}^{-1} \mathrm{~h}^{-1}\right)\right)$ were measured in eight normal volunteers and in eight duodenal ulcer subjects. The rate of secretion in both groups fell by $25 \%$ without any statistically significant change in pyloric loss or duodenogastric reflux. It is concluded that smoking reduces gastric secretion. The possibility that relative antral hypoacidity induced by regular smoking produces an increase in parietal cell mass via a feedback mechanism mediated by gastrin is discussed: such a mechanism would explain the previously reported positive correlation between maximal gastric secretion of acid and the total dose of cigarettes.
\end{abstract}

(Gut 1992; 33: 1170-1173)

In 1604 James I of England published his famous Counterblaste to Tobacco in which he made what was probably the earliest statement on the effects of smoking on gastric secretion: '.. and by causing over quick digestion, fill the stomach full of crudites.'

Nearly 400 years later three major studies have shown that maximal gastric secretory capacity is increased in smokers compared with nonsmokers, in both controls and those with duodenal ulcers. ${ }^{2+}$ This increase in gastric secretion showed a positive correlation to the total number of cigarettes smoked. ${ }^{5}$

To determine whether acute smoking has an acute effect on gastric secretion that can explain the findings of the chronic studies, the effect of this on gastric secretion was studied using the same methods as those used in the chronic studies of Whitfield and Hobsley. ${ }^{6}$

\section{Methods}

Eight healthy volunteers considered free from peptic ulcer disease (controls) and eight patients with endoscopically proved duodenal ulcer disease were studied. Before the study, which was always performed in the morning, all subjects were starved for eight hours, avoided all medicines known to affect the gastrointestinal tract for at least 12 hours, and refrained from smoking for at least 24 hours.

The effects of smoking a single cigarette of the subject's normal brand were studied on an approximately $50 \%$ submaximal plateau of gastric secretion. All subjects studied were regular smokers but the duodenal ulcer patients were significantly older and had therefore smoked for a longer period (Table I). The demographic data for the two groups are shown in Table I. Gastric secretion was corrected for pyloric loss using phenol red, and for duodenogastric reflux, using the sodium content of the aspirate. Gastric secretion thus corrected is referred to as $\mathrm{Vg}$ and is measured in $\mathrm{ml} / \mathrm{h} .{ }^{6} \mathrm{Vg}$ reflects the true volume of gastric secretion under test conditions since any artefact caused by changes in pyloric loss and duodenogastric reflux is removed. Basal secretion was measured before the induction of the submaximal plateau - formal maximal studies were not performed as this would have made the test unacceptably long. Maximal values of $\mathrm{Vg}$ for similar groups are shown to allow comparison. The submaximal plateau was started after a one hour basal period. The submaximal plateau lasted for three hours, and half way through this the subject smoked one cigarette at the usual rate. The submaximal plateau was induced with an intravenous infusion of histamine acid phosphate $(16 \mathrm{nmol}$ $\mathrm{kg}^{-1} \mathrm{~h}^{-1} ; 0.005 \mathrm{mg} \mathrm{kg}^{-1} \mathrm{~h}^{-1}$ ) because previous work in this department has shown that this concentration will produce a plateau of secretion that is about $50 \%$ of maximal. ${ }^{7}$ The informed consent of the subjects and the permission of the Clinical Investigations Panel had been given.

\section{Results}

VG

In the control group, the median $\mathrm{Vg}$ before smoking was $145.8 \mathrm{ml} \mathrm{h}^{-1}$; after smoking a single cigarette gastric secretion fell by $23 \%$ to $112 \cdot 2 \mathrm{ml} \mathrm{h}^{-1}$; this was significant $(\mathrm{p}<0.05)$. In duodenal ulcer patients the median $\mathrm{Vg}$ before smoking was $237.6 \mathrm{ml} \mathrm{h}^{-1}$; after smoking a single cigarette there was a $26 \%$ fall in $\mathrm{Vg}$ to a median value of $175.2 \mathrm{ml} \mathrm{h}^{-1}(\mathrm{p}<0.02)$ (Table I). The median $\mathrm{Vg}$ in each group for each 10 minute collection period was found and plotted against time to show the relation between the change in Vg and cigarette smoking. In both the controls and the duodenal ulcer subjects the new lower plateau of gastric secretion was attained by the end of 11th collection period, about 20 minutes after beginning to smoke the cigarette (Figs 1 and 2).

\section{PYLORIC LOSS}

In the control patients pyloric loss was $16.8 \mathrm{ml}$ TABLE I Subject demography (median values)

\begin{tabular}{lcc}
\hline Patient details & Controls & $\begin{array}{l}\text { Duodenal ulcer } \\
\text { patients }\end{array}$ \\
\hline No & $8 \cdot 0$ & $8 \cdot 0$ \\
Males & 2 & 8 \\
Age & $23 \cdot 5^{\star}$ & $51 \cdot 1$ \\
Height $(\mathrm{cm})$ & $168 \cdot 0$ & $166 \cdot 0$ \\
Weight $(\mathrm{kg})$ & $71 \cdot 5$ & $65 \cdot 0$ \\
Cigarettes $/ \mathrm{day}$ & $20 \cdot 0$ & $20 \cdot 0$ \\
Basal $\mathrm{Vg}(\mathrm{ml} / \mathrm{h})$ & $58 \cdot 8^{\star}$ & $117 \cdot 0$ \\
Maximal $\mathrm{Vg}(\mathrm{ml} / \mathrm{h})$ & $237 \cdot 6^{\star}$ & $380 \cdot 4$ \\
\hline
\end{tabular}

$\mathrm{Vg}=$ corrected gastric secretion, see Methods. ${ }^{\star} \mathrm{p}=0.02$.
Department of Surgery 
TABLE II Median Vg, pyloric loss $(P L)$ and duodenogastric reflux (DGR) expressed as $\mathrm{ml} / \mathrm{h}$ in controls and duodenal ulcer subjects before and after smoking a single cigarette

\begin{tabular}{|c|c|c|c|c|c|}
\hline \multirow[b]{2}{*}{ Controls: } & \multirow[t]{2}{*}{ Range } & \multicolumn{3}{|c|}{ Before $\mathcal{E}$ after smoking } & \multirow[t]{2}{*}{ Range } \\
\hline & & & & & \\
\hline $\mathrm{Vg}$ & $(78.0$ to 243.0$)$ & $145 \cdot 8$ & $<0.05$ & $112 \cdot 2$ & $(25 \cdot 8$ to $218 \cdot 4)$ \\
\hline PL & $(-27 \cdot 6$ to $37 \cdot 8)$ & $16 \cdot 8$ & NS & $16 \cdot 8$ & $(-10 \cdot 2$ to $33 \cdot 6)$ \\
\hline DGR & $(-7.8$ to 90.0$)$ & $1 \cdot 3$ & NS & 0.7 & $(-7 \cdot 2$ to $21 \cdot 6)$ \\
\hline \multicolumn{6}{|l|}{ Duodenal ulcer group: } \\
\hline VG & (93.6 to 472.8$)$ & $237 \cdot 6$ & $<0.02$ & $175 \cdot 2$ & $(87.0$ to 383.4$)$ \\
\hline PL & $(-46 \cdot 2$ to $159 \cdot 6)$ & $30 \cdot 0$ & NS & $37 \cdot 5$ & $(-32 \cdot 4$ to $70 \cdot 8)$ \\
\hline DGR & $(13.2$ to $51 \cdot 0)$ & $33 \cdot 0$ & NS & $14 \cdot 7$ & $(11 \cdot 4$ to $55 \cdot 8)$ \\
\hline
\end{tabular}

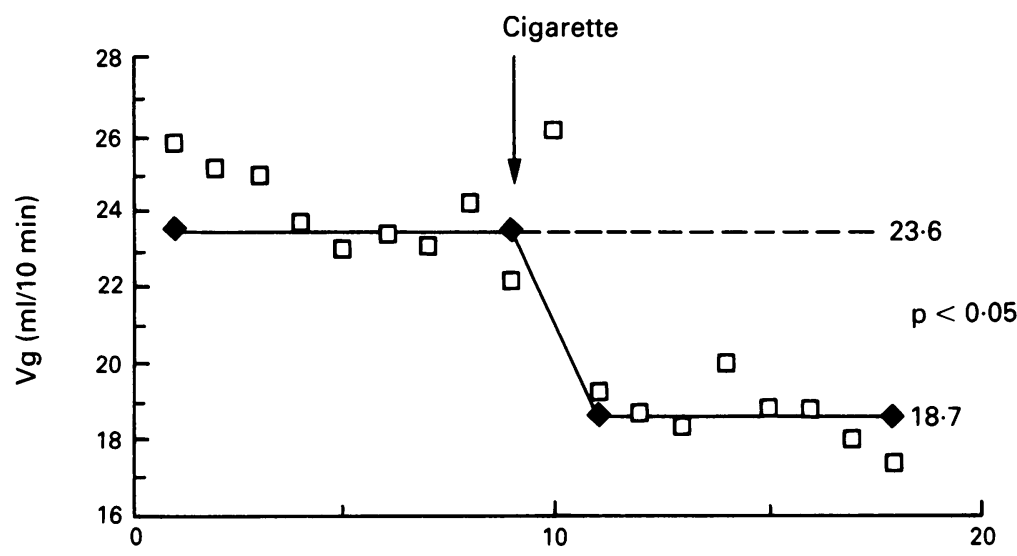

Collection periods

Figure 1: Median gastric secretion $(\mathrm{Vg})$ for each 10 minute period for the control group before and after smoking a single cigarette (plateau level shown as line).

$\mathrm{h}^{-1}$ before smoking and was unchanged afterwards; an apparent rise in the duodenal ulcer patients from $30 \mathrm{ml} \mathrm{h}^{-1}$ to $37.5 \mathrm{ml} \mathrm{h}^{-1}(25 \%)$ was not significant (Table I). In both controls and duodenal ulcer subjects the plateau of pyloric loss was not as stable as that of $\mathrm{Vg}$. There was no discernible change in the pattern of pyloric loss in relation to the smoking of a single cigarette.

\section{DUODENOGASTRIC REFLUX}

In both groups there was a fall of about $50 \%$ in duodenogastric reflux after smoking a single cigarette (controls, $1 \cdot 3-0 \cdot 7 \mathrm{ml} \mathrm{h}^{-1}$ and patients, $33 \cdot 0-14 \cdot 7 \mathrm{ml} \mathrm{h}^{-1}$ (Table I). However, in neither group did this reach significance. Again, no change in the pattern of duodenogastric reflux related to the smoking of a single cigarette could be discerned.

In summary, acute cigarette smoking caused a

Figure 2: Median gastric secretion $(\mathrm{Vg})$ for each 10 minute period for duodenal ulcer subjects before and after smoking a single cigarette (plateau level shown as line).

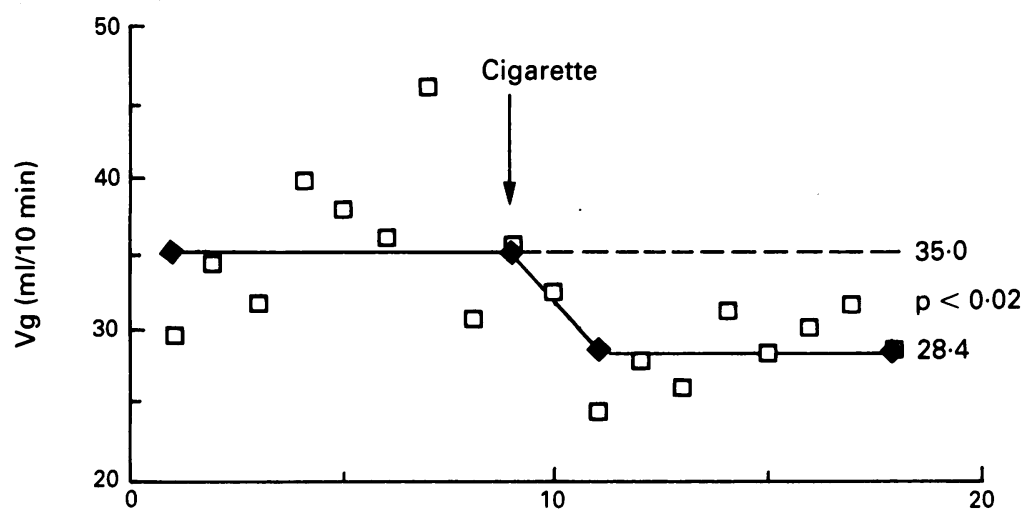

Collection periods

\section{Discussion}

Analysis of the results showed remarkable uniformity in the change in Vg after smoking a single cigarette. In 15 of 16 subjects studied there was a fall in $\mathrm{Vg}$, and in both control and patient groups this was of the order of $25 \%$ (range, 1.9$66 \cdot 7 \%$ ). The effect of smoking did not seem to be greater in one group than the other; the percentage fall was the same in both. Although factors such as stature, age, and duodenal ulcer disease affect the absolute values of $\mathrm{Vg}$ they can have little or no effect on the changes in someone consequent upon smoking a cigarette: thus despite the small numbers studied the $25 \%$ fall is highly significant.

This fall in Vg might, however, be an artefact caused by 'fade'. 'Fade' is a pharmacological phenomenon in which the response of a steady state system to a given stimulus decreases with time; thus it might be argued that the cigarette smoking had no effect and that the observed reduction in secretion simply coincided with system fade. Work from this unit, in which seven subjects were subjected to a three hour submaximal histamine stimulation preceded by a one hour basal period, did not show any evidence of fade. ${ }^{7}$ This is in agreement with other workers who have shown that fade does not occur with histamine. ${ }^{8}$

It is also possible that the fall in $\mathrm{Vg}$ is an indirect result of smoking, because nausea has been shown to inhibit significantly pentagastrin stimulated gastric secretion. ${ }^{9}$ No subject, however, complained of nausea or any other gastrointestinal tract symptoms at any time during the submaximal plateau.

Over the years there have been many studies of the effects of smoking on gastric secretion. The results have varied, showing no effect in some $e^{\mid t-12}$ and decreased secretion in others. ${ }^{13-15}$ Many studies can be discounted since they have used unnatural smoking protocols, or basal or maximal gastric secretion as a plateau. Basal secretion is variable over short time periods and is also subject to the errors inherent in low volume collections. Maximal stimulation overcomes these criticisms but cannot show a stimulatory effect and may well swamp any inhibitory effect of smoking. A submaximal infusion of either pentagastrin or histamine to produce about $50 \%$ stimulation is ideal. This produces a steady state in which any stimulatory or inhibitory effects can be measured. The studies that fulfil these two simple criteria are few. The volume and acidity of aspirated gastric juice are the net result of gastric secretions, duodenogastric reflux, pyloric loss, and swallowed saliva. The failure to account for pyloric loss and duodenogastric reflux means that any true change in gastric secretion could be masked by changes in transpyloric fluid flux; the effect of swallowed saliva is at present impossible to correct for. The only other study that made corrections for pyloric loss and duodenogastric reflux came to conclusions that are the same as ours. ${ }^{15}$

After smoking a single cigarette there is a significant nicotine and carboxyhaemoglobin boost which reaches its peak within 10 minutes. ${ }^{1617}$ The half-life of nicotine ${ }^{18}$ and carboxyhaemoglobin ${ }^{17}$ is thought to be approxi- 
mately two hours. These chronological events relate well with the acute changes in gastric secretion seen after smoking a single cigarette (Figs 1 and 2).

Chronic nicotine administration to rats in a dose equivalent to a daily consumption of $10-15$ cigarettes a day produced a significant increase in basal gastric secretion. The acute response to nicotine in these chronically treated rats was a significant decrease in gastric secretion. ${ }^{19}$ In man, nicotine given parenterally has been shown to have an acute inhibitory action on the gastric secretion. ${ }^{1314}$

Carboxyhaemoglobin concentrations have not been studied in direct relation to gastric secretion in man but this agent may cause relative anoxia of the cell; both anoxia and the thiocyanate ion (another cigarette product) have been shown to prevent the transformation by histamine of a resting parietal cell to its active acid secreting state. ${ }^{202}$

It has been shown (see introduction) that chronic smoking leads to a chronically raised gastric secretory capacity in both control and duodenal ulcer subjects, and that the secretory capacity of an individual is related solely to the size of his parietal cell mass, and not to any change in the sensitivity of those cells; this also appears to be the case in smokers. ${ }^{7}$ Acute cigarette smoking has been shown to reduce $\mathrm{Vg}$ significantly in controls and duodenal ulcer subjects. Is there any evidence that links these acute and chronic changes in $\mathrm{Vg}$ which occur in relation with cigarette smoking?

Gastrin is released from the antral G cell and stimulates the parietal cell to secrete hydrochloric acid into the gastric lumen ${ }^{22}$ : the acid then acts on the antrum to inhibit further release of gastrin and hence of hydrochloric acid. ${ }^{23}$ Any factor that interferes with this negative feedback loop could lead to a rise in gastrin values. It has been shown, for example, that taking antacids is associated with a rise in serum gastrin provided that alkalisation occurs, ${ }^{24}$ and that chronic acid inhibition with $\mathrm{H}_{2}$ antagonists leads to a rise in serum gastrin in both rats ${ }^{25}$ and humans. ${ }^{26}$ Thus, the chronic 20 cigarette a day smoker exposes himself to regular falls in gastric secretion associated with each cigarette smoked. This could in turn lead to interference with the normal negative feedback loop and result in a rise in the circulating gastrin values; indeed serum gastrin has been found to rise significantly after cigarette smoking in patients with duodenal ulcer disease ${ }^{27}$ Recent work has shown that the maximal acid output and antral mucosal gastrin values were significantly raised in smokers compared with non-smokers with duodenal ulcer disease; there was though no difference in the parietal cell sensitivity to gastrin between smokers and non-smokers. The authors concluded that increased antral gastrin is important in the pathogenesis of an increased maximal acid output in smokers with a duodenal ulcer. ${ }^{28}$

If acute smoking and the associated fall in gastric secretion lead to a rise in circulating gastrin, what effect could this have? As well as regulating the parietal cell secretion of $\mathrm{H}^{+}$and $\mathrm{Cl}^{-}$ions, gastrin is known to have a tropic effect on the parietal cells independent of its secretory potential; this has been shown experimentally ${ }^{29} 30$ and clinically; patients with the ZollingerEllison syndrome have an abnormally high circulating gastrin with marked gastric mucosal hyper-plasia and an increased parietal cell count. ${ }^{31}$

It could also be argued that the increased maximal secretory capacity of smokers is the result of chronic vagal stimulation which enhances acid secretion. If this were the case one would also expect to find increased basal secretion in smokers - in our study this was not the case. In 48 controls and 106 duodenal ulcer patients we found no evidence of increased basal Vg in smokers compared with non-smokers.?

We conclude that acute cigarette smoking causes a significant fall in gastric secretion $(\mathrm{Vg})$, and suggest that this results in raised gastrin values that have a tropic effect on the parietal cell, thereby accounting for the raised secretory capacity of chronic smokers.

This work forms part of a MS thesis accepted by the University of London 1990.

James I of England and VI of Scotland. Counterblaste to Tobacco. London, 1604.

2 Whitfield PF, Hobsley M. Smoking and gastric hypersecretion in duodenal ulcer patients. Gut 1979; 20: A918.

3 Parente F, Lazzaroni M, Sangaletti O, Baroni S, Porro GB. Cigarette smoking, gastric acid secretion, and serum cigarette smoking, gastric acid secretion, and serum 1985; 26: 1327-32.

4 Massarrat S, Enschai F, Pittner PM. Increasing gastric secretory capacity in smokers without gastrointestinal esions. Gut 1986; 27: 433-9.

5 Whitfield PF, Hobsley M. Comparison of maximal gastric secretion in smokers and non-smokers with and withou duodenal ulcer. Gut 1987; 28: 557-60.

6 Whitfield PF, Hobsley M. A standardised technique for the performance of accurate gastric secretion studies. Agents Actions 1979; 94: 327-32.

7 Roxburgh JC. The acute and chronic effects of cigarette smoking upon various aspects of gastric secretion [Thesis] London: University of London, 1989.

8 Aubrey DA. The effects on human gastric secretion of prolonged continuous intravenous infusions of maximal and supra-maximal doses of histamine acid phosphate and pentagastrin. Gut 1970; 11: 392-4.

9 Cohen MM, Debas HT, Holubitsky IB, Harrison RC. Effect of nausea on human gastric secretory responses. Dig $D i$ 1971; 16: 156-9.

10 Debas HT, Cohen MM. Effect of smoking on gastric secretion stimulated by pentagastrin. Lancet 1972; i: $43-4$.

11 Fung WP, Tye CY. Effect of smoking on gastric acid. Aust NZ Med f 1973; 3: 251-4.

12 Whitecross DP, Clarke AD, Piper DW. The effect of cigarette smoking on human gastric secretion. Scand $\mathcal{F}$ Gastroenterol 1974; 9: 399-403.

13 Wilkinson AR, Johnson D. Inhibitory effect of cigarette smoking on gastric secretion stimulated by pentagastrin in man. Lancet 1971 ; ii: $628-32$.

14 Sonnenberg A, Husmert N. Effect of nicotine on gastric mucosal blood flow and acid secretion. Gut 1982; 23: 532-5.

15 Fletcher DR, Shulkes A, Hardy KJ. The effect of cigarette smoking on gastric secretion and mucosal blood flow in man Aust NZ Med F 1985; 15: 417-20.

16 Armitage AK, Dollery CT, George CF, Houseman TH, Lewis PJ, Turner DM. Absorption and metabolism of nicotin from cigarettes. $B M \mathcal{F} 1975 ; 4$ : 313-6.

17 Ashton $\mathrm{H}$, Telford R. Blood carboxyhaemoglobin levels in smokers. $B M 7$ 1973; 4:740.

18 Isaac PF, Rand MJ. Cigarette smoking and plasma levels of nicotine [Letter]. Nature 1974; 236: 308-10.

19 Thompson JH, Spezia CA, Angulo M. Chronic effects of nicotine on gastric secretion in vagotomised rats. Experientia nicotine on gastric

20 Helander HF. Parietal cell structure during inhibition of acid secretion. Scand f Gastroenterol 1984; 19 (suppl 101): 21-6.

21 Hersey SJ, Chew CS, Campbell L, Hopkins E. Mechanism of action of SCN-1 in isolated gastric glands. Am F Physio 1981; 240: G232-8.

22 Malinowska DH, Sachs G. Cellular mechanisms of acid secretion. In: Isenberg JI, Johansson C, eds. Clinics in gastroenterology. Philadelphia: WB Saunders, 1984: 309-27.

23 Adrian TE, Forgacs IC, Keeling PWN, Thompson RPH Regulatory peptides of the foregut. In: Baron JH, Moody FG, eds. Foregut. London: Butterworths, 1981: 68-73.

24 Feule GE. Effect of rising intragastric $\mathrm{pH}$ induced by severa antacids on serum gastrin concentration in duodenal ulcer patients and in a control group. Gastroenterology 1975; 68: patients.

25 Sundler F, Hakanson R, Carlsson E, Larson H, Mattsson H. Hypergastrinaemia after blockade of acid secretion in the rat: trophic effects. Digestion 1986; 35 (suppl 1): 56-83. 
26 Hakanson R, Hedenbro J, Liedberg G, Rehfeld J, Stadil F. Activation of histidine decarboxylase by $\mathrm{H} 2$-receptor blockade:

27 Brandsborg O, Christensen NJ, Galbo H, Brandsborg M, Lovegreen NA. The effect of exercise, smoking and propranolol on serum gastrin in patients with duodenal ulcer and vagotomised subjects. Scand $\mathcal{F}$ Clin Lab Invest 1978; 38: $441-6$.

28 Hui WM, Chan M, Lam SK. Smoking affects mucosal gastrin and gastric acid secretion in duodenal ulcer. Gut 1987; 28 : A1374.
29 Crean GP, Marshall MW, Rumsey RDE. Parietal cell hyperplasia induced by the administration of pentagastrin to rats. plasia induced by the administr

30 Johnson LR. The trophic action of gastrointestinal hormones. Gastroenterology 1976; 70: 278-88

31 Elison EH, Wilson SD. Further observations on factor influencing the symptomatology manifest by patients with Zollinger-Elison syndrome. In: Shuitka TK, Gilbert JAL, Harrison RC, eds. Gastric secretion. New York: Pergamon Press, 1967: 363-9. 